\title{
SIKAP MASYARAKAT MADURA TERHADAP TRADISI CAROK: Studi Fenomenologi Nilai-Nilai Budaya Masyarakat Madura
}

\author{
Rokfyanto dan Marsuki \\ IKIP Budi Utomo Malang \\ e-mail: rochyanto_mhum@yahoo.co.id; marsukigani@yahoo.com
}

\begin{abstract}
This paper describes personal and communal attitudes of Maduranese towards carok and the reasons of existing carok. The study's approach is descriptive involving 195 Maduranese. Observation, questionnaire, and interview were implemented to collect data. Result of analysis shows 4 personal attitudes toward carok as follow: 75\% accept that they are not intend to do carok, 60\% accept that they will not do carok in any reason, $77.38 \%$ accept to solve all cases wisely without doing carok, and (4) $77.40 \%$ will not do carok because of being obedient to state and religious rules. While 5 Maduranese communal attitudes toward carok involve: $64.16 \%$ accept that carok is not Madura tradition, $81.11 \%$ accept that Madura community love peace, $86.11 \%$ agree that carok does not represent Maduranese, $82.44 \%$ agree that carok is bad rules, and $76.11 \%$ accept to solve all cases wisely without carok. It is also concluded that the motivation of carok are women, misunderstanding, inheritance, belief, theft, and debt problems.
\end{abstract}

Studi ini bertujuan mendeskripsikan sikap individu dan kelompok orang Madura terhadap tradisi carok serta alasan-alasan terjadinya carok. Penelitian ini menggunakan pendekatan deskriptif dengan subyek berjumlah 195 orang. Instrumen yang digunakan adalah pengamatan, angket, dan wawancara. Berdasarkan hasil analisis, ditemukan 4 sikap individu terhadap carok meliputi 75\% tidak senang memiliki tradisi carok, 60\% tidak melakukan carok, 77,38\%, menyelesaikan persoalan secara bijak tanpa carok, dan 77,40 tidak melakukan carok karena taat terhadap hukum negara dan agama. Sedangkan 5 sikap kelompok orang Madura terhadap carok meliputi: 64,16\% menerima aarok bukanlah budaya 
orang Madura, 81,11\% menyatakan masyarakat Madura cinta damai, 86,11\% menyatakan carok tidak mewakili orang Madura, 82,44\% menerima carok merupakan perbuatan keji dan melanggar hukum, dan 76,11\% menyatakan akan menyelesaikan persoalan secara bijak tanpa carok. Selain itu, ditemukan bahwa motif-motif terjadinya carok adalah karena wanita, kesalahpahaman, warisan, keyakinan, pencurian dan) hutang piutang.

Keywords: attitude, carok, tradition, Madura

\section{Pendahuluan}

Kata "Madura" dalam benak sebagian orang akan terbayang alam yang tandus, perilaku yang kasar dan arogan bahkan menakutkan. Citra negatif yang paling kentara adalah mengenai "carok" dan "clurit". Jadi kata carok yang konon membuat miris hati, perasaan dan jiwa, sangat identik dengan aroma kekerasan, karena yang ada dalam bayangan adalah tindakan perkelahian dengan menggunakan senjata tajam berbentuk celurit, melengkung dan sangat tajam pada bagian ujungnya. Stereotip ini, meskipun tidak selalu mencerminkan realitas yang sebenarnya, antara lain menyebutkan orang Madura keras perilakunya, kaku, ekspresif, temperamental, pendendam, dan suka melakukan tindak kekerasan, sering kali mendapatkan pembenaran, ketika terjadi kasus-kasus kekerasan di mana pelakunya orang Madura.

Hasil penelitian dan fakta-fakta tentang budaya Madura berikut ini tentu menolak generalisasi dan kesimpulan sikap negatif yang dialamatkan pada orang-orang Madura. Pertama, majalah Tempo berdasarkan riset pada tahun 1980-an pernah menempatkan suku Madura dalam lima besar suku yang paling sukses di negara ini. Mereka dikenal sebagai sosok yang rajin, ulet, berkinerja tinggi, agamis, dan bersikap terbuka terhadap perubahan (Tempo Interaktif, 16 Agustus 2006). Budaya Madura sebenarnya sarat dengan nilainilai positif, hanya saja kemudian nilai-nilai positif itu tertutupi dengan sikap dan perilaku negatif sebagian orang Madura (Wiyata, 2006: 18). Masyarakat yang tidak pernah ke Madura memiliki gambaran yang kelam tentang orang Madura yang diliputi penuh dengan rasa kekhawatiran dan cemas. Akan tetapi, setelah mereka tinggal di pulau Madura, hampir 180 derajat pandangannya berubah tentang orang Madura. Orang Madura ternyata sangat santun, ramah, akrab, dan hangat dalam menerima tamu. Untuk itu, dibutuhkan suatu studi atau penelitian lebih lanjut demi terbukanya wawasan masyarakat mengenai nilai-nilai budaya Madura yang selama ini disalahpersepsikan (Giring, 2004: 91). 
Perilaku carok tidak akan muncul begitu saja, melainkan ada penyebab yang sangat esensial. Pemicu utama dari budaya carok adalah ketika harga diri dan martabat seseorang terlukai, tercemar ataupun terinjak-injak. Dengan kata lain, kadangkala carok terjadi karena persoalan-persoalan yang menyangkut ketersinggungan harga diri seseorang. Kasus carok ini di antaranya pernah terjadi dan menelan 7 jiwa di kabupaten Pamekasan pada bulan Juni 2007. Darah kering masih menghiasi jalan utama Desa Bujur Tengah, Kecamatan Batu Marmar, Pamekasan, Madura, Jawa Timur. Peristiwa carok merupakan suatu pembunuhan yang sangat keji dan sadis yang diatasnamakan untuk mempertahankan harga diri yang tercabik. Kekejaman, kekejian, dan kesadisan dapat dilihat dari kondisi korban carok. Tubuh para korban penuh luka bacokan, bahkan terkadang terpotong-potong sampai beberapa bagian. Kalau pada awalnya tragedi carok dipicu oleh sesuatu yang esensial dan prinsipil, namun lambat-laun persoalan bergeser pada masalah "martabat dan harga diri”. Pergeseran pada persoalan-persoalan sepele dan kecil tersebut seperti perbedaan dari tiap personal (pribadi) yang mampu menjadi pemicu carok, misalnya melanggar kesopanan, persoalan anak-anak, penghinaan dan persoalanpersoalan kecil yang mampu membakar emosi.

Perkembangannya budaya carok lambat-laun bisa terkikis dari masyarakat tradisional Madura. Hal itu disebabkan oleh gesekan dengan budaya yang datang dari luar Madura selain akses pendidikan yang telah memasuki sendisendi kehidupan. Dengan demikian budaya carok sebagai warisan lama, secara perlahan akan punah, apalagi senjata yang biasa dipakai untuk carok, yaitu celurit telah berubah fungsi menjadi "Celurit Emas". Gambaran inilah yang secara terus-menerus didengungkan dan dikumandangkan oleh D. Zawawi Imron (1986), penyair dan budayawan Madura untuk menepis sekaligus menghapus pandangan tentang orang Madura yang senantiasa digambarkan sosok yang keras, angkuh, egois, kumuh, bromocorah, masyarakat pinggiran dengan aksen kental logat Madura yang amburadul.

Dari fakta-fakta di atas, maka penelitian ini bertujuan untuk meneliti sikap individu maupun kelompok orang Madura tentang pandangan mereka terhadap tradisi carok dan alasan-alasan yang memicu terjadinya perilaku carok di pulau Madura. Penelitian ini sangat penting dilakukan seiring dengan adanya faktor-faktor seperti perkembangan peradaban dan perubahan tatanan sosial, pesatnya arus teknologi dan informasi yang semakin meluas, perubahan pola pikir dan sikap karena pendidikan dan pengalaman, serta pergantian generasi dari waktu ke waktu di pulau Madura. 
Sikap didefinisikan sebagai kesediaan untuk bereaksi (disposition to react) secara positif (favorably) atau secara negatif (unfavorably) terhadap obyek-obyek tertentu (Sarwono, 2000: 27). Sikap juga dimaknai sebagai kecenderungan bertindak, berpersepsi, berpikir, dan merasa dalam menghadapi objek, ide, situasi, atau nilai (Rakhmat, 1992: 39). Sementara, Azwar (2003) mendefinisikan sikap sebagai suatu pola perilaku, tendensi atau kesiapan antisipatif, predisposisi untuk menyesuaikan diri dalam situasi sosial, atau secara sederhana, sikap adalah respon terhadap stimulus sosial yang telah terkondisikan. Dengan demikian, sikap merujuk pada pandangan atau perasaan yang disertai kecenderungan untuk bertindak terhadap obyek tertentu yang senantiasa diarahkan kepada sesuatu artinya tidak ada sikap tanpa obyek. Selain itu, Fitri (2008) berpendapat bahwa sikap diarahkan kepada benda-benda, orang, peristiwa, pandangan, lembaga, norma dan lain-lain. Berdasarkan pendapatpendapat tersebut dapat disimpulkan bahwa sikap adalah keadaan diri dalam manusia yang menggerakkan untuk bertindak atau berbuat dalam kegiatan sosial dengan perasaan tertentu di dalam menanggapi obyek situasi atau kondisi di lingkungan sekitarnya. Selain itu sikap juga memberikan kesiapan untuk merespon yang sifatnya positif atau negatif terhadap obyek atau situasi.

Budaya Madura sesungguhnya sarat dengan nilai-nilai sosial budaya yang positif. Hanya saja kemudian nilai-nilai positif tersebut tertutupi sikap dan perilaku negatif sebagian orang Madura sendiri, sehingga muncul stereotip tentang orang Madura, dan lahir citra yang tidak menguntungkan. Lebih daripada itu, pandangan mereka terhadap masyarakat dan kebudayaan Madura selalu cenderung negatif. Nilai-nilai sosial sebuah budaya bersifat lokal dan kontekstual sesuai dengan kondisi dan karakteristik masyarakat pendukungnya. Sejalan dengan ini, seharusnya budaya Madura mencerminkan karakteristik masyarakat yang religius yang beradab dan sederetan sikap dan watak positif lainnya. Akan tetapi, keluhuran nilai budaya tersebut pada sebagian orang Madura tidak mengejawantah karena muncul sikap-sikap yang oleh orang lain dirasa tidak menyenangkan (Giring, 2004: 91).

Kata 'tradisi' dan 'budaya' adalah dua kata yang sering digunakan dalam makna yang sama dalam merujuk pada makna kebiasaan atau adat suatu masyarakat tertentu. Terkait dengan penelitian ini, dua kata itu memiliki hubungan yang sangat erat. Budaya memiliki cakupan yang lebih luas daripada tradisi. Budaya sebagai wujud ideal yang bersifat abstrak yang tidak dapat diraba dalam pikiran manusia yang dapat berupa ide, gagasan, norma, dan keyakinan (Koentjaraningrat, 1989: 22). Jadi, budaya yang merupakan hasil 
karya manusia melalui cipta, rasa dan karsanya dibentuk dari aneka ragam tradisi, pola pikir, kebiasaan, karya, seni, dan sebagainya. Dalam hal ini, budaya memiliki cakupan dan ruang lingkup yang lebih luas.

Carok dapat dilakukan secara ngonggai (menantang duel satu lawan satu) atau nyelep (menikam musuh dari belakang). Di zaman awal kemunculannya, carok banyak dilakukan dengan cara ngonggai. Semenjak dekade 1970-an terdapat pergeseran bahwa carok kadangkala dilakukan dengan cara nyelep. Dengan adanya kebiasaan melakukan carok dengan cara nyelep maka etika yang bermakna kejantanan bergeser menjadi brutali dan egois. Fenomena ini terjadi pada kaum laki-laki yang tidak mau disebut seperti kaum perempuan yang hanya bertengkar dengan mulut. Kaum laki-laki membuat semboyan sendiri bahwa kaum perempuan mempunyai mulut dua sehingga suka bertengkar dengan kata-kata sedangkan kaum laki-laki mempunyai senjata sehingga sangat naif bahkan pecundang jika tidak bertengkar dengan senjata.

Konon di wilayah Madura pedalaman, tradisi carok itu sampai teruntemurun. Keluaga yang menjadi korban carok akan meyimpan baju yang bersangkutan (meninggal) pada tetangganya yang kelak akan diperlihatkan pada anaknya setelah dewasa, bahwa ayahnya mati karena carok atau dibunuh si X setelah itu anak yang bersangkutan akan menuntut balas dengan mencari dan membunuh pembunuh ayahnya dan begitu juga seterusnya sampai kerungan selanjutnya. Kebiasaan tersebut terjadi pada masyarakat yang latar belakang pengetahuannya masih sangat rendah dan termasuk ke dalam kategori pandalungan.

Ada banyak teori tentang konflik kekerasan orang Madura yang disebut dengan carok ini. Secara umum, pendapat-pendapat tersebut sama-sama menyatakan bahwa carok adalah konflik kekerasan orang Madura yang timbul dan disebabkan karena persoalan harga diri. Teori-teori tersebut banyak dikemukakan oleh orang-orang luar Madura berdasarkan hasil pengamatanpengamatan, seperti yang dilakukan oleh Van Dijk, Touwen - Bouwsma, dan De Jonge (Latief, 2006: 16-20). Sementara, sebagian kecil di antaranya dinyatakan oleh orang Madura sendiri dengan metode yang lebih akurat, yaitu dengan melakukan serangkaian penelitian-penelitian tentang carok.

\section{Metode Penelitian}

Penelitian ini menggunakan pendekatan deskriptif kuantitatif-kualitatif karena data penelitian ini bersifat deskriptif yang berupa makna, konsep, definisi, ciri-ciri, metafora, symbol-simbol, dan pendeskripsian suatu objek 
dengan angka-angka deskriptif (Marsuki, 2003: 34). Data penelitian ini berupa hasil pengamatan di lapangan, hasil angket, wawancara, penjelasan-penjelasan tokoh masyarakat Madura serta dokumen-dokumen tentang tradisi budaya tentang carok di pulau Madura. Sumber data dalam penelitian ini merujuk pada subyek atau responden orang-orang Madura pada umumnya, orangorang Madura yang pernah melakukan carok, dan para pemuka atau tokoh masyarakat Madura.

Penelitian ini melakukan pengambilan sampel dengan sistem multistage sampling yang didasarkan atas keterwakilan pada aspek: 1) daerah/tempat tinggal yang tersebar di 4 kabupaten Madura yaitu Bangkalan, Sampang, Pamekasan, dan Sumenep; 2) tingkat pendidikan; 3) profesi; 4) tingkat ekonomi; dan 5) jenis kelamin. Untuk jumlah responden atau sampel dari masyarakat Madura dapat dijelaskan sebagai berikut: 1) 180 orang yang menjawab angket; 2) 10 orang yang berpengalaman bercarok yang diwawancarai; dan 3) 5 orang yang diwawancarai sebagai tokoh masyarakat Madura.

\section{Sikap Individu Orang Madura terhadap Tradisi Carok}

Data penelitian ini adalah jawaban angket yang melibatkan 180 responden sebagai perwakilan orang Madura yang memiliki latar belakang pendidikan, profesi, lapisan masyarakat, dan tingkat ekonomi yang berbeda-beda yang tersebar di 4 kabupaten yaitu Bangkalan, Sampang, Pamekasan, dan Sumenep. Angket yang disebarkan kepada orang Madura terdiri dari 20 pernyataan sebagai sikap individu orang Madura terhadap tradisi carok.

Berikut ini sebaran 4 kelompok sikap yang sesuai dengan sikap-sikap dalam pernyataan pada angket:

Tabel 1. Sikap individu orang Madura terhadap tradisi carok dalam persentase

\begin{tabular}{|l|c|c|c|c|c|c|}
\hline $\begin{array}{l}\text { Sikap Individu orang Madura terhadap } \\
\text { tradisi carok }\end{array}$ & Menerima & $\%$ & Menolak & $\%$ & $\begin{array}{c}\text { Ragu- } \\
\text { Ragu }\end{array}$ & $\%$ \\
\hline $\begin{array}{l}\text { 1. Sikap "Senang dan bangga memiliki } \\
\text { budaya dan tradisi carok" }\end{array}$ & 66 & 18,33 & 270 & 75 & 24 & 6,66 \\
\hline $\begin{array}{c}\text { 2. Sikap "Melakukan carok demi membe- } \\
\text { la harga diri dan keluarga keluarga" }\end{array}$ & 168 & 31,11 & 324 & 60 & 48 & 8,88 \\
\hline $\begin{array}{c}\text { 3. Sikap "Menyelesaikan segala persoalan } \\
\text { dengan bijak tanpa melakukan carok }\end{array}$ & 975 & 77,38 & 179 & 14,20 & 106 & 8,41 \\
\hline $\begin{array}{c}\text { 4. Sikap "Taat dan Tunduk terhadap hu- } \\
\text { kum negara dan agama }\end{array}$ & 418 & 77,40 & 63 & 11,66 & 59 & 10,92 \\
\hline
\end{tabular}


Berdasarkan temuan hasil penelitian tentang 4 sikap individu orang Madura terhadap carok dapat dideskripsikan sebagai berikut. Pertama, secara individu orang Madura yang bersikap bahwa mereka tidak bangga dan senang memiliki budaya dan tradisi carok menunjukkan angka 75\% jauh lebih besar dari mereka yang bersikap bangga dan senang memiliki budaya dan tradisi budaya carok yang menunjukkan angka 18,33\%. Sedangkan mereka yang bersikap ragu-ragu adalah 6,66\%. Kedua, orang Madura yang bersikap bahwa mereka tidak akan bercarok walaupun untuk membela harga diri dan keluarga tetapi mencari penyelesaian yang lebih bijak menunjukkan angka $60 \%$ lebih besar daripada mereka yang bersikap melakukan carok yang menunjukkan angka 31,11\%. Sedangkan mereka yang bersikap ragu-ragu adalah 8,88\%. Ketiga, orang Madura yang bersikap menyelesaikan segala persoalan secara bijak tanpa melakukan carok menunjukkan angka 77,38\% lebih besar dari mereka yang bersikap sebaliknya yang menunjukkan angka 14,20. Sedangkan mereka yang bersikap ragu-ragu adalah $8,41 \%$. Keempat, orang Madura yang bersikap bahwa carok itu melanggar hukum agama, khususnya hukum syariat Islam dan hukum negara menunjukkan angka 77,40\% lebih tinggi dari mereka yang bersikap sebaliknya yang menunjukkan angka 11,66\%. Sedangkan mereka yang bersikap ragu-ragu adalah 10,92\%.

Hasil ini menunjukkan bahwa kebanyakan orang Madura tidak setuju bahwa carok itu adalah tradisi dan budaya orang Madura. Mereka lebih suka menyelesaikan persoalan dengan bijak tanpa adanya kekerasan walaupun persoalan itu menyangkut harga diri. Mereka juga menyadari bahwa perbuatan itu adalah melanggar hukum agama dan negara. Oleh karena itu, perilaku carok adalah perbuatan dosa besar yang melanggar perintah Allah SWT. Namun demikian, hasil temuan ini juga menunjukkan bahwa carok masih terjadi di 4 kabupaten pulau Madura yaitu Bangkalan, Sampang, Pamekasan, dan Sumenep. Temuan ini memperkuat hasil penelitian sebelumnya yang menyatakan bahwa kasus carok karena membela harga diri dan kehormatan keluarga masih menjadi sikap sebagian orang Madura (Wiyata, 2006: 230). Perbuatan ini tentunya tidak mewakili masyarakat Madura, tetapi lebih bersifat personal dan lokal. Bagaimanapun juga, nilai-nilai negatif yang dilakukan oleh beberapa atau sebagian kecil orang Madura ini mampu menutupi nilai-nilai positif yang dilakukan sebagian besar orang Madura (Wiyata, 2006: 18). 


\section{Sikap Kelompok Orang Madura terhadap Tradisi Carok}

Seperti cara yang dilakukan di atas, berikut disajikan rekapitulasi hasil angket yang dikelompokkan ke dalam 5 kelompok sikap kelompok orang Madura terhadap tradisi carok.

Tabel 2. Sikap kelompok orang Madura terhadap tradisi carok dalam prosentase

\begin{tabular}{|c|c|c|c|c|c|c|}
\hline $\begin{array}{l}\text { 1. Sikap Kelompok orang Madura } \\
\text { terhadap tradisi carok }\end{array}$ & Merima & $\%$ & Menolak & $\%$ & $\begin{array}{c}\text { Ragu- } \\
\text { Ragu }\end{array}$ & $\%$ \\
\hline $\begin{array}{c}\text { 2. Carok bukanlah budaya dan tradisi } \\
\text { orang Madura. }\end{array}$ & 231 & 64,16 & 92 & 25,55 & 37 & 10,27 \\
\hline $\begin{array}{c}\text { 3. Masyarakat Madura adalah } \\
\text { masyarakat yang cinta damai dan me- } \\
\text { nyukai perubahan yang positif tanpa } \\
\text { kekerasan seperti melakukan carok. }\end{array}$ & 146 & 81,11 & 13 & 7,22 & 21 & 11,66 \\
\hline $\begin{array}{c}\text { 4. Perbuatan carok tidak mewakili sikap } \\
\text { orang Madura pada umumnya. }\end{array}$ & 155 & 86,11 & 18 & 10 & 7 & 3,88 \\
\hline $\begin{array}{c}\text { 5. Carok adalah perbuatan keji dan } \\
\text { mungkar dan melanggar hukum } \\
\text { negara dan agama. }\end{array}$ & 742 & 82,44 & 84 & 9,33 & 74 & 8,22 \\
\hline $\begin{array}{c}\text { 6. Menyelesaikan segala persoalan } \\
\text { secara bijak tanpa melakukan carok } \\
\text { termasuk persoalan harga diri dan } \\
\text { keluarga. }\end{array}$ & 137 & 76,11 & 25 & 13,88 & 18 & 10 \\
\hline
\end{tabular}

Hasil penelitian tentang sikap kelompok orang Madura terhadap carok meliputi 5 sikap. Pertama, secara umum atau kelompok, orang Madura yang bersikap bahwa carok bukanlah budaya dan tradisi orang Madura pada umumnya menunjukkan angka 64,16\% lebih tinggi dari mereka yang bersikap sebaliknya yaitu $25,55 \%$. Sedangkan mereka yang bersikap ragu-ragu menunjukkan angka 10,27\%. Kedua, mereka yang bersikap bahwa orang Madura adalah orang yang cinta damai dan menyukai perubahan yang positif, menunjukkan angka $81,11 \%$ jauh lebih tinggi dari mereka yang bersikap sebaliknya yaitu 7,22\%. Sedangkan mereka yang bersikap ragu-ragu hanyalah 11,66\%. Ketiga, orang Madura yang bersikap bahwa perbuatan carok tidak mewakili perilaku orang Madura pada umumnya menunjukkan angka $86,11 \%$ jauh lebih tinggi dari mereka yang bersikap sebaliknya yaitu $10 \%$. Sedangkan mereka yang bersikap ragu-ragu adalah 3,88\%. Keempat, orang Madura yang bersikap bahwa carok adalah perbuatan keji dan mungkar dan melanggar hukum negara dan agama, menunjukkan angka 82,44\% lebih tinggi daripada mereka yang bersikap sebaliknya yaitu $9,33 \%$. Sedangkan mereka yang bersikap ragu-ragu 
adalah 8,22\%. Kelima, orang Madura yang bersikap bahwa orang Madura menyelesaikan segala persoalan secara bijak tanpa melakukan carok termasuk persoalan harga diri dan keluarga, menunjukkan angka 76,11\% jauh lebih besar daripada mereka yang bersikap sebaliknya yaitu 13,88\%. Sedangkan mereka yang bersikap ragu-ragu adalah $10 \%$.

Hasil ini menunjukkan sikap kelompok orang Madura yang positif seperti halnya temuan pada sikap individu orang Madura sebelumnya. Mereka kebanyakan tidak senang dengan kehadiran carok karena perbuatan itu adalah perbuatan yang keji, mungkar, melanggar hukum agama dan negara. Mereka tidak setuju dengan semboyan "etembang pote mata lebih bagus pote tolang". Mereka lebih suka menyelesaikan segala persoalan termasuk harga diri dengan jalan bijak baik melalui jalan kekeluargaan maupun jalan hukum. Namun demikian, perilaku carok masih menjadi fakta yang dapat dijumpai dan terjadi di Madura meski hanya sebagian kecil. Oleh karena itu, jika ada orang yang melakukan kekerasan di pulau Madura dan melanggar nilai-nilai agama dan hukum negara, maka hal ini tidak dapat disimpulkan dan digeneralisasikan sebagai perwakilan orang Madura secara keseluruhan. (Wiyata, 2006: 18).

\section{Alasan-Alasan yang Memicu Terjadinya Carok di Madura}

Berdasarkan analisis data khususnya data wawancara dengan orang-orang Madura yang memiliki pengalaman bercarok, tokoh masyarakat Madura serta data yang diperoleh dari hasil pengamatan, bahwa perilaku carok disebabkan oleh persoalan-persoalan hidup yang meliputi persoalan istri atau perempuan, kesalahpahaman, persoalan warisan dan tanah, agama atau keyakinan, pencurian, dan hutang-piutang.

Pertama, salah satu motif carok karena persoalan perempuan atau istri terjadi pada tahun 1985 di Desa Pandian Sumenep antara Ismail dan Abd. Rapik. Motifnya adalah karena istri Ismail digoda oleh Abd.Rapik yang pada akhirnya keduanya saling mencintai. Ismail merasa tidak sudi sehingga mereka dendam untuk membunuh Abd.Rapik. Maka terjadilah carok hingga mengalami luka tetapi tidak ada yang mengalami korban hingga meninggal dunia pada waktu itu.

Kedua, carok juga terjadi karena kesalahpahaman. Kejadian ini terjadi pada tahun 2009 tepatnya 1 November 2009 hari Minggu malam telah terjadi peristiwa carok massal di Desa Bulangan Timur Kecamatan Pegantenan Pamekasan Madura. Carok massal ini melibatkan dua kelompok yang dipimpin oleh Ustadz Ruslan warga desa Tebul Timur yang berprofesi sebagai guru 
madrasah dan Rusdi warga Desa Bulangan Timur Kecamatan Pegantenan Pamekasan. Motif peristiwa carok ini adalah kesalahpahaman yang bermula dari pemukulan keponakan ustadz Ruslan yang bernama Muzakki oleh Rusdi pada 30 Oktober 2009, satu hari sebelum kejadian. Carok ini menewaskan 1 orang meninggal dunia dan 3 orang luka-luka.

Ketiga, carok juga disebabkan oleh persoalan warisan dan tanah. Salah satu kasus motif ini terjadipada tanggal 12 tepatnya hari Rabu bulan Juli 2007, yaitu terjadinya carok massal di Desa Bujur Tengah Kecamatan Batu Marmar Kabupaten Pamekasan yang melibatkan dua kubu yaitu kubu Kepala Desa Bujur tengah, Mursyidin dan mantan Kepala Desa Bujur Tengah, Baidlowi. Peristiwa carok massal ini bermula dari sengketa lahan tembakau seluas 5,8 hektare yang dikenal sebagai tanah bengkok. Masyarakat desa percaya, tanah itu adalah peninggalan Kerajaan Majapahit yang kemudian menjadi aset desa atau percaton. Akibat dari perselisihan ini, terjadilah carok massal yang pada akhirnya menewaskan sedikitnya delapan warga Desa Bujur Tengah Batu Marmar, Pamekasan, Madura, termasuk Mursyidin dan ibunya.

Keempat, carok di pulau Madura kadangkala bisa terjadi disebabkan oleh persoalan agama atau keyakinan. Agama atau keyakinan yang dimaksud disini adalah termasuk perbedaan paham walaupun dalam satu agama. Perbedaan paham atau aliran dapat memicu terjadinya konflik yang mengarah pada carok. Alasan ini telah dilakukan konfirmasi kepada mereka yang dianggap tokoh masyarakat dan memiliki pengalaman bercarok. Persoalan agama dianggap sesuatu yang sangat vital dalam masyarakat Madura khususnya agama Islam. Bahkan perbedaan paham bagi sebagian orang Madura yang mengarah pada pelecehan atau penghinaan agama khususnya agama Islam dapat menyebabkan konflik horizontal yang dapat bermotif carok.

Kelima, mengambil hak orang lain atau mencuri berdasarkan hasil analisis data merupakan salah satu pemicu dan motif terjadinya carok di Madura. Salah satu kasus carok karena pencurian pernah terjadi di Desa Batuan Sumenep di tahun 1960. Peristiwa ini bermula dari 2 orang yang bernama Tajir dan Ismail. Pada suatu ketika, Tajir yang bekerja di luar kota selalu menitipkan uang dari hasil kerjanya, pakaian dan barang-barang kebutuhan lainnya untuk istri dan keluarganya di Sumenep kepada Ismail yang ingin pulang kampung. Pemberian kiriman ini sering dilakukan oleh Tajir melalui Ismail. Pada suatu ketika Tajir menanyakan kepada keluarganya tentang uang, pakaian dan lainlain yang dikirimkan melalui Ismail. Tetapi sang istri menjawab bahwa tak ada satupun kiriman itu yang ia terima. Mendengar masalah ini, Tajir segera 
mendatangi Ismail dan menanyakan hal kiriman tersebut. Karena sudah terlanjur malu dan diketahui Tajir, Ismail langsung menantang Tajir bercarok. Dalam duel carok ini, Ismail tewas sedangkan Tajir dihukum dan mendekam di Nusa Kambangan.

Hasil temuan terkait alasan terjadinya carok pada umumnya bermuara pada membela harga diri karena dilecehkan, dihina, dan tidak dihargai (tada'ajina) sehingga mereka menanggung malu dan bisa menjadi masalah yang berkepanjangan dengan menaruh dendam. Ketika dendam itu terbalaskan, mereka menjadi puas. Dari 6 motif di atas, persoalan perempuan atau istri yang memicu paling banyak terjadinya carok di Madura. Menurut hasil wawancara dengan beberapa tokoh masyarakat Madura, persoalan perempuan kebanyakan memicu terjadinya carok (tak bisa ebacco yang berarti tidak bisa dicuci) sedangkan motif persoalan-persoalan lain selain kasus perempuan atau istri masih bisa dilakukan pertimbangan-pertimbangan. Hasil ini juga didukung oleh hasil penelitian sebelumnya bahwa persoalan perempuan merupakan motif yang sangat rawan mengundang terjadinya konflik kekerasan yang disebut carok hingga menunjukkan angka prosentase 60,4\% (Wiyata,2006: 91).

Motif berikutnya adalah kesalahpahaman hingga mencapai 16,9\% kemudian diikuti oleh motif hutang piutang dan tanah warisan yang masingmasing menunjukkan 9,2\% dan 6,7\% (Wiyata, 2006: 91). Selain kasus-kasus di atas, persoalan agama atau keyakinan khususnya khilafiyah atau perbedaan pendapat tentang suatu perkara hukum Islam juga menjadi pemicu terjadinya carok. Hal ini mengingat karena orang Madura termasuk orang yang tunduk pada agama yang kental dengan paham Nahdatul Ulama serta taat pada tokoh atau pemuka agama seperti ulama (Tempo Interaktif, 16 Agustus 2006). Orang Madura berpendirian bahwa agama adalah hal suci yang harus dibela dan merupakan pedoman bagi orang Madura. Siapapun yang menghina agama maka harus diperangi. Sebagian besar agama orang Madura adalah Islam. Dalam hal ini, Hasan (2012) mengatakan bahwa agama Islam sudah meresap dan mewarnai kehidupan sosial, mulai dari cara berperilaku, berpakaian, cara makan, bahkan cara tidurpun mengikuti ajaran agama.

Ungkapan orang Madura yang berkaitan dengan betapa fanatiknya mereka terhadap agama adalah "abhantal syahadat, asapo' iman, apajung Allah, asandhing Nabbhi" yang berarti berbantal syahadat, berselimut iman, berpayung Allah, dan bersanding dengan Nabi Muhammad. Ungkapan ini adalah ungkapan orang Madura yang menggambarkan bahwa orang Madura menjiwai agama Islam. Itulah sebabnya, adanya Organisasi Fokus yang terdiri 
dari Nahdatul Ulama, Persis, Muhammadiyah, Al Irsyad, SI, Hidayatullah, serta masuknya MUI dan LP2SI diharapkan dapat menekan angka carok di Pamekasan. Sementara, Ketua Muhammadiyah Pamekasan yang termasuk dalam Organisasi Fokus, Imam Santoso mengatakan, adanya masalah khilafiyah saat ini menjadi permasalahan tersendiri. Perbedaan di masyarakat tentang hari Lebaran dan paham kerap kali membuat emosi masyarakat tak terkendali sehingga, masalah agama bisa berujung pada carok.

\section{Simpulan}

Dalam penelitian ini telah ditemukan 4 sikap individu dan 5 sikap kelompok orang Madura terhadap tradisi carok serta alasan-alasan pemicu terjadinya carok di pulau Madura. Pertama, berdasarkan hasil analisis ditemukan 4 sikap individu orang Madura terhadap carok yang meliputi sebagai berikut: $75 \%$ tidak senang dan tidak bangga memiliki budaya dan tradisi carok; sebanyak $60 \%$ responden menyatakan tidak melakukan carok walaupun alasan demi membela harga diri dan keluarga; sebanyak 77,38\% menatakan akan menyelesaikan segala persoalan secara bijak tanpa melakukan carok, dan $77,40 \%$ menyatakan tidak melakukan carok karena taat dan tunduk terhadap hukum negara dan agama.

Kedua, sedangkan 5 sikap kelompok orang Madura terhadap carok adalah: $64,16 \%$ responden menyatakan carok bukanlah tradisi dan budaya orang Madura; sebanyak 81,11\% menyatakan masyarakat Madura adalah masyarakat yang cinta damai; sebanyak $86,11 \%$ menyatakan perbuatan carok tidak mewakili orang Madura pada umumnya; sebanyak 82,44\% menyatakan carok adalah perbuatan keji dan mungkar dan melanggar hukum negara dan agama; sebanyak $76,11 \%$ responden menyatakan akan menyelesaikan segala persoalan secara bijak tanpa melakukan carok.

Ketiga, alasan terjadinya carok pada umumnya bermuara pada membela harga diri karena dilecehkan, dihina, dan tidak dihargai (tada'ajina). Perkembangannya budaya carok lambat-laun bisa terkikis dari masyarakat tradisional Madura disebabkan faktor pendidikan, pergeseran waktu, pergantian generasi, dan lingkungan sangat mempengaruhi sikap dan pola pikir mereka untuk lebih berpikir jernih.

\section{Daftar Pustaka}

Azwar S. 2003. Sikap Manusia. Yogyakarta: Pustaka. Pelajar

Berg, B. L. 1989. Qualitative Research Method for Social Sciences. Boston. 
Massachusetts: Allyn and Bacon.

Fitri. 2008. Pengertian Sikap. http:// Blog dunia Psikologi. Com, diakses 7 April 2010

Giring. 2004. Madura di Mata Dayak: Dari Konflik Ke Rekonsiliasi (Edisi pertama). Yogyakarta: Galang Press.

Hasan, N. 2012. Abhantal Syahadat, Asapo' Iman, Apajung Allah, Asandhing Nabhi. http://www.lontarmadura.com/abhantal-syahadat-asapo-iman, diakses 18 Juli 2013.

Imron, D. Z. 1986. Menggusur Carok. Surabaya: Harian Memorandum.

Koentjaraningrat. 1989. Pengantar Ilmu Antropologi. Jakarta: PT. Gramedia

Marsuki. 2003. The Representation of Cooperative Principle in Earnest Miller Hemingway's The Sun Also Rises. Malang: Unpublished Thesis, PPS UM.

Rakhmat, J. 1992. Retorika Modern: Pendekatan Praktis. Bandung: PT Remaja Rosdakarya.

Sarwono, S. 2000. Pengantar Psikologi Umum. Jakarta: Rajawali Pers.

Tempo Interaktif, 16 Agustus 2006.

Tim Penyusun Kamus Besar Bahasa. 2001. Kamus Besar Bahasa Indonesia (Ed. 3.Cet.1). Jakarta: Balai Pustaka.

Wiyata, A. L. 2006. Carok, Konflik Kekerasan dan Harga Diri Orang Madura, Yogyakarta: PT LKiS Pelangi Aksara.

el Harakah Vol.17 No.1 Tahun 2015 